\title{
Energy and economic advantages of simultaneous hydrogen and biogas production in microbial electrolysis cells as a function of the voltage and biomass
}

\author{
Ariadna Segundo-Aguilar ${ }^{\mathrm{a}}$, Linda V. González-Gutiérrez ${ }^{\mathrm{a}}$, Víctor Climent Payáb, Juan Feliu ${ }^{\mathrm{b}}$, \\ Germán Buitrón ${ }^{\mathrm{c}}$, Bibiana Cercado ${ }^{\mathrm{a}^{*}}$
}

${ }^{a}$ Centro de Investigación y Desarrollo Tecnológico en Electroquímica S.C. Parque Tecnológico Querétaro Sanfandila, 76703, Pedro Escobedo, Querétaro, Mexico.

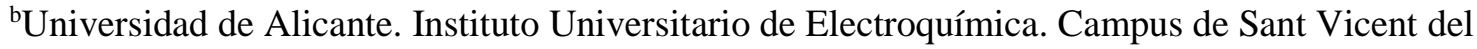
Raspeig. Apt. 99 E-03080 Alacant, Spain

${ }^{\mathrm{c}}$ Laboratorio de Investigación en Procesos Avanzados de Tratamiento de Aguas, Unidad Académica Juriquilla, Instituto de Ingeniería, Universidad Nacional Autónoma de México, Campus Juriquilla, UNAM. Blvd. Juriquilla No. 3001, 76230 Querétaro, Mexico.

*Corresponding author: Tel.: +52(442) 2116000

E-mail address: bcercado@cideteq.mx (B. Cercado)

\begin{abstract}
Energy and economic data of gaseous biofuels production in microbial electrolysis cells (MECs) is a guide for its operation mode, reactor design, and scaling. Hydrogen and methane production from wastes mainly depend on the cell voltage and biomass content and their interactions. In the present work, energy efficiencies and economic benefits were stablished for simultaneous dual production of hydrogen and biogas in a cation membrane two-chamber MEC. Several combinations of biomass content $(5-75 \%)$ and cell voltage $(0.30-1.20 \mathrm{~V})$ were tested for biogas and hydrogen production at the anodic and cathodic compartments, respectively. Biogas and hydrogen reached $33 \mathrm{~mL}$ and 3.5 $\mathrm{mL}$ within 13 days. The highest energy efficiency for hydrogen was $854 \%$ which was obtained at $0.3 \mathrm{~V}$ and $40 \%$ biomass whilst the highest methane production rate was $14.4 \mathrm{~mL} \mathrm{~L}^{-1} \mathrm{~d}^{-1}$ with $0.43 \mathrm{~V}$ and $65 \%$ biomass. The highest economic gain was obtained through the production of biogas with a surplus of $20 \%$ due to the simultaneous production of hydrogen, reaching 0.010 USD per $\mathrm{kg}$ COD removed. The data generated under the comprehensive operation conditions will support decisionmaking about MEC design, operation, scaling and likely as well for technical-economic studies.
\end{abstract}


Keywords: applied voltage; biogas; biomass content; economic benefits; energy efficiency; hydrogen

\section{Highlights}

- MECs were inoculated and fed with effluents from a food-waste digester

- Gaseous biofuels production was monitored as a function of voltage and biomass content

- The highest cathodic hydrogen volume was $3.5 \mathrm{~mL}$ in the MEC with $0.3 \mathrm{~V}-40 \% \mathrm{BM}$

- The highest anodic biogas volume was $33 \mathrm{~mL}\left(87 \% \mathrm{CH}_{4}\right)$ with $0.43 \mathrm{~V}-65 \% \mathrm{BM}$

- Biogas and hydrogen dual production resulted in an economic benefit of 0.010

USD/removed COD 


\section{Introduction}

Microbial electrolysis cells (MEC) are a technology still in development that accomplishes multiple functions which include pollution removal, desalinization, hydrogen, biogas and other valuable chemicals production from wastewater [1 Kadier et al. 2016]. Because of the versatility of MECs, they can be coupled to energy producing bioprocesses as well as to depollution of liquid and semisolid organic waste discharges, thus increasing energy yield in a biorefinery scheme [2 Borole A.P. 2015].

MECs are complex systems that involve biological and electrochemical processes. A standard MEC consists of an anodic and a cathodic compartment, separated by a selective exchange membrane. An electroactive biofilm grows on the anode and oxidizes organic matter, producing electrons and protons in the anodic chamber. The ions migrate from one electrolyte to the other through the membrane while the electrons are transferred from the biofilm to the anode and then flow through an external circuit to the cathode. The electrons arriving to the cathode combine with ions to form valuable chemicals such as hydrogen. MECs with separated chambers allow collecting the gases separately, while membrane-less designs provide a gas mixture that evolves over time. This process is driven by the application of a fixed potential between the anode and a reference electrode using a potentiostat or between anode and cathode using a power source [3 Liu et al. 2012].

MEC startup procedure has been studied in terms of the volatile solids/chemical oxygen demand ratio in the medium [4 Dhar et al. 2015]. That ratio was first evaluated in culture flasks to select an optimum value and then, this optimum value was applied to an MEC. In another study, a direct correspondence between volatile solids and electrical current production was found in tests using half bioelectrochemical cells, but experiments in whole MECs were not performed [5 Cercado et al. 2013]. Based on these related works, knowledge on the effect of volatile solids and chemical oxygen demand on MEC performance could be extended to a wide range using effectively whole MECs.

Studies on the effect of the concentration of the substrate on MECs have revealed that low concentration may limit microbial growth and activity, whereas high concentration may be detrimental for the electrochemical processes due to the divergence of the electron flow [6 Kadier et al. 2014, 7 Luo et al. 2016]. Because of the possible antagonist effect of substrate concentration, a screening of substrate concentration becomes necessary to determine the optimal concentration for each specific MEC system. 
High energy efficiency is one of the main challenges for MEC operation. Energy efficiency is calculated on the basis of the energy applied as cell voltage and the energy recovered as either hydrogen or methane [8 Selembo et al. 2009, 9 Villano et al. 2016]. In consequence, to optimize the energy efficiency, it is necessary to minimize the energy consumption (voltage) and maximize the gaseous biofuel production through the screening of applied voltage in the MECs.

Historically, methane has been reported as a typical pollutant of a hydrogen flow, already in the very early studies, and hydrogen production has been disregarded in studies focusing on methane production because it is seen only as one intermediate in the process of methane formation. Since dual production of these gaseous biofuels is not frequent, information on global energy efficiency and its associated economic benefits is lacking.

Table 1 shows previous reports on hydrogen and biogas production. Rader et al. (2010) [18] and Ruiz et al. (2013) [13] showed a higher volumetric productivity for hydrogen than for methane; on the contrary, Feng et al. (2015) [11] showed a higher yield for methane than for hydrogen. Tartakovsky et al (2008 [19], 2009) [16] compared the input energy needed as a function of the presence of a membrane, and from the same research group, the volume of hydrogen and methane as a function of the applied voltage was reported using a similar experimental setup (Escapa et al. 2013) [17].

Although Rader et al. (2010) [18] signaled an increase in energy efficiency due to dual production of biofuels, this advantage was not further explored. Moreover, Guo et al. (2013) [12] focused on dual production from anaerobic sludge in a single-chamber membrane-less reactor. Since the production of methane was subsequent to that of hydrogen, the authors proposed separation of gaseous currents. The question in this work is whether the system could be considered an MEC, since the electrodes were constructed with $\mathrm{Ti} / \mathrm{Ru}$ and no evidence of bioelectrode formation at voltages $1.4 \mathrm{~V}$ and $1.8 \mathrm{~V}$ was presented.

The above short review highlights that dual productivity of gaseous biofuels is still contradictory and that an integrative analysis of the most critical parameters is necessary to verify the economic benefits from simultaneous hydrogen and methane production in MECs.

In the present work simultaneous production of cathodic hydrogen and anodic biogas was investigated as a function of applied voltage $\left(\mathrm{V}_{\text {app }}\right)$ and biomass content $(\% \mathrm{BM})$ in an H-type MEC installed with a selective membrane. The combinations $\mathrm{V}_{\text {app }} \% \mathrm{BM}$ that enabled the highest energy efficiencies were identified and then the corresponding economic benefits were calculated. The information and data obtained over a wide range of applied voltages and biomass content is valuable for MEC design, operation, scaling and, likely, also useful for techno-economic studies. 
Table 1 Characteristics and performance of MEC systems that report dual production of hydrogen and biogas. Data is classified as function of the electrodes separator.

\begin{tabular}{|c|c|c|c|c|c|c|c|c|c|}
\hline \multirow{2}{*}{$\begin{array}{c}\text { Target } \\
\text { product }\end{array}$} & \multirow[t]{2}{*}{ Inoculum } & \multirow[t]{2}{*}{ Substrate } & \multirow{2}{*}{$\begin{array}{c}\text { Electrochemical } \\
\text { cell }\end{array}$} & \multirow{2}{*}{$\begin{array}{c}\text { Voltage } \\
\text { (V) }\end{array}$} & \multicolumn{2}{|c|}{ Gaseous biofuels } & \multicolumn{2}{|c|}{ Efficiency (\%) } & \multirow[t]{2}{*}{ Reference } \\
\hline & & & & & Hydrogen & Methane & Cathodic & Energy & \\
\hline & \multicolumn{9}{|c|}{ Membrane-less MEC } \\
\hline Hydrogen & $\begin{array}{l}\text { MFC } \\
\text { effluent }\end{array}$ & $\begin{array}{l}\text { Acetate } \\
1 \mathrm{~g} / \mathrm{L}\end{array}$ & $\begin{array}{l}\text { A: Brush } \\
\text { C: Carbon cloth- } \\
\mathrm{Pt} \\
28 \mathrm{~mL}\end{array}$ & $0.3-0.8$ & $\begin{array}{l}3.12 \\
\mathrm{~m}^{3} / \mathrm{m}^{3} / \mathrm{d} \\
(0.8 \mathrm{~V}) \\
2.5 \\
\mathrm{~m}^{3} / \mathrm{m}^{3} / \mathrm{d} \\
(0.6 \mathrm{~V})\end{array}$ & $\begin{array}{l}30 \% \\
(0.2 \mathrm{~V}) \\
10 \% \\
(0.3 \mathrm{~V})\end{array}$ & 78 to 96 & $\begin{array}{l}406 \\
\text { to } \\
94\end{array}$ & $\begin{array}{l}\text { [10] Call \& } \\
\text { Logan, } \\
2008\end{array}$ \\
\hline $\begin{array}{l}\text { Methane } \\
\text { but } \\
\text { reported } \\
\text { both }\end{array}$ & $\begin{array}{l}\text { UASB } \\
\text { sludge }\end{array}$ & $\begin{array}{l}\text { Sludge } \\
4.3 \mathrm{~g} \\
\mathrm{COD} / \mathrm{L}\end{array}$ & $\begin{array}{l}\text { A: Fe tube } \\
\text { C: Graphite } \\
2.0 \mathrm{~L}\end{array}$ & $\begin{array}{l}0.3 \\
0.6\end{array}$ & $\begin{array}{l}84 \% \\
15 \mathrm{~L} / \mathrm{kg} \\
\mathrm{VS}\end{array}$ & $\begin{array}{l}22 \% \\
170 \mathrm{~L} \\
\mathrm{CH}_{4} / \mathrm{kg} \\
\mathrm{VS}(0.3 \\
\mathrm{V}) \\
96 \mathrm{~L} \\
\mathrm{CH}_{4} / \mathrm{kg} \\
\mathrm{VS}(0.6 \\
\mathrm{V})\end{array}$ & $\mathrm{Nr}$ & $\mathrm{Nr}$ & $\begin{array}{l}\text { [11] Feng et } \\
\text { al. } 2015\end{array}$ \\
\hline $\begin{array}{l}\text { Hydrogen } \\
\text { and } \\
\text { methane }\end{array}$ & $\begin{array}{l}\text { Sludge } \\
148 \mathrm{~mL}\end{array}$ & $\begin{array}{l}\text { Nutrients } \\
\text { solution }\end{array}$ & $\begin{array}{l}\mathrm{A} \text { and } \mathrm{C} \text { : } \\
\mathrm{Ti} / \mathrm{Ru} \\
300 \mathrm{~mL}\end{array}$ & $\begin{array}{l}1.4 \\
1.8\end{array}$ & $\begin{array}{l}\text { Before } 5 \\
\text { days } \\
2.5 \mathrm{~mL} \\
7.7 \mathrm{~mL}\end{array}$ & $\begin{array}{l}\text { After } 5 \\
\text { days } \\
163 \mathrm{~mL} \\
137 \mathrm{~mL}\end{array}$ & $\mathrm{Nr}$ & $\mathrm{Nr}$ & $\begin{array}{l}\text { [12] Guo et } \\
\text { al. } 2013\end{array}$ \\
\hline $\begin{array}{l}\text { Hydrogen } \\
\text { but } \\
\text { reported } \\
\text { both }\end{array}$ & $\begin{array}{l}\text { MFC } \\
\text { effluent }\end{array}$ & $\begin{array}{l}\text { Acetate } \\
4 \mathrm{mM}\end{array}$ & $\begin{array}{l}\text { A: Brush } \\
\text { C: Carbon cloth } \\
1.3 \mathrm{~L}\end{array}$ & 1.2 & $\begin{array}{l}100 \mathrm{~mL} \\
(50 \mathrm{~h})\end{array}$ & $\begin{array}{l}65 \mathrm{~mL} \\
(65 \mathrm{~h})\end{array}$ & 4 & $\mathrm{Nr}$ & $\begin{array}{l}\text { [13] Ruiz et } \\
\text { al. } 2013\end{array}$ \\
\hline Hydrogen & $\begin{array}{l}\text { Swine } \\
\text { wastewater }\end{array}$ & $\begin{array}{l}\text { Swine } \\
\text { wastewater } \\
2 \mathrm{COD} \mathrm{g} / \mathrm{L}\end{array}$ & $\begin{array}{l}\text { A: Brush } \\
\text { C: Carbon-Pt } \\
28 \mathrm{~mL}\end{array}$ & 0.5 & $\begin{array}{l}77 \% \\
10-88 \mathrm{~mL} \\
0.9-1.0 \\
\mathrm{~m}^{3} / \mathrm{m}^{3} / \mathrm{d}\end{array}$ & $13 \%$ & 29 to 61 & $\begin{array}{l}190 \\
(42 \mathrm{~h}) \\
91 \\
(184 \mathrm{~h})\end{array}$ & $\begin{array}{l}{[14]} \\
\text { Wagner et } \\
\text { al. } 2009\end{array}$ \\
\hline $\begin{array}{l}\text { Hydrogen } \\
\text { but } \\
\text { reported } \\
\text { both }\end{array}$ & $\begin{array}{l}\text { MFC } \\
\text { effluent }\end{array}$ & $\begin{array}{l}\text { Acetate } \\
1 \mathrm{~g} / \mathrm{L}\end{array}$ & $\begin{array}{l}\text { A: Brush } \\
\text { C: Carbon cloth- } \\
\mathrm{Pt} \\
43 \mathrm{~mL}\end{array}$ & $\begin{array}{l}0.7 \\
0.6-0.9 \\
0.4\end{array}$ & $\begin{array}{l}92 \%(12 \\
\text { h) } \\
88 \%(24 \\
\text { h) } \\
37 \%(72 \\
\text { h) } \\
25 \%(0.3 \\
\text { V) } \\
90 \%(0.6 \\
\text { V) }\end{array}$ & $\begin{array}{l}3 \%(12 \\
\text { h) } \\
2.8 \%(24 \\
\text { h) } \\
4 \%(72 \\
\text { h) } \\
50 \%(0.3 \\
\text { V) } \\
5 \%(0.6 \\
\text { V) }\end{array}$ & $\mathrm{Nr}$ & $\mathrm{Nr}$ & $\begin{array}{l}\text { [15] Wang } \\
\text { et al. } 2009\end{array}$ \\
\hline
\end{tabular}




\begin{tabular}{|c|c|c|c|c|c|c|c|c|c|}
\hline Hydrogen & $\begin{array}{l}\text { Anaerobic } \\
\text { sludge }\end{array}$ & $\begin{array}{l}\text { Acetate } \\
4 \mathrm{~g} / \mathrm{L} / \mathrm{d}\end{array}$ & $\begin{array}{l}\text { A: Felt } \\
\text { C: Gas } \\
\text { diffusion-Pt } \\
50 \mathrm{~mL}\end{array}$ & $\begin{array}{l}0.4- \\
1.15\end{array}$ & $\begin{array}{l}0.09-6.3 \\
\text { L/L/d }\end{array}$ & $\begin{array}{l}0.008- \\
0.99 \\
\text { L/L/d }\end{array}$ & $\mathrm{Nr}$ & $\begin{array}{l}1.5-6.5 \\
\mathrm{Wh} / \mathrm{L}_{\mathrm{H} 2}\end{array}$ & $\begin{array}{l}{[16]} \\
\text { Tartakovsky } \\
\text { et al. } 2009\end{array}$ \\
\hline & \multicolumn{9}{|c|}{ MEC with electrodes separator } \\
\hline Hydrogen & $\begin{array}{l}\text { Anaerobic } \\
\text { sludge }\end{array}$ & $\begin{array}{l}\text { Synthetic } \\
\text { dark } \\
\text { fermentation } \\
\text { effluent } \\
6.4 \\
\text { COD/L/d }\end{array}$ & $\begin{array}{l}\text { A : Graphite felt } \\
\text { C: Diffusion } \\
\text { cathode-Ni } \\
\text { J-cloth } \\
210 \mathrm{~mL}\end{array}$ & $0.6-0.1$ & $\begin{array}{l}1.42 \\
\mathrm{~L} / \mathrm{L}_{\mathrm{a}} / \mathrm{d} \\
(1.0 \mathrm{~V}) \\
0.8 \mathrm{~L} / \mathrm{L}_{\mathrm{a}} / \mathrm{d} \\
(0.8 \mathrm{~V}) \\
0.25 \\
\mathrm{~L} / \mathrm{L}_{\mathrm{a}} / \mathrm{d} \\
(0.6 \mathrm{~V})\end{array}$ & $\begin{array}{l}1.0 \\
\mathrm{~L} / \mathrm{L}_{\mathrm{a}} / \mathrm{d} \\
(1.0 \mathrm{~V}) \\
1.1 \\
\mathrm{~L} / \mathrm{L}_{\mathrm{a}} / \mathrm{d} \\
(0.8 \mathrm{~V}) \\
1.3 \\
\mathrm{~L} / \mathrm{L}_{\mathrm{a}} / \mathrm{d} \\
(0.6 \mathrm{~V})\end{array}$ & $\begin{array}{l}53.8 \\
\text { to } \\
68.6\end{array}$ & $\begin{array}{l}94.3 \\
\text { to } \\
131.3\end{array}$ & $\begin{array}{l}\text { [17] Escapa } \\
\text { et al. } 2013\end{array}$ \\
\hline $\begin{array}{l}\text { Hydrogen } \\
\text { but } \\
\text { reported } \\
\text { both }\end{array}$ & $\begin{array}{l}\text { MFC } \\
\text { effluent }\end{array}$ & $\begin{array}{l}\text { Acetate } 1 \\
\mathrm{~g} / \mathrm{L} \\
1.67 \mathrm{~L} / \mathrm{min}\end{array}$ & $\begin{array}{l}\text { A: Brush } \\
\text { C: Stainless } \\
2.5 \mathrm{~L}\end{array}$ & 0.9 & $\begin{array}{l}0.53 \mathrm{~L} / \mathrm{L} / \mathrm{d} \\
1300 \mathrm{~mL} \\
(3 \mathrm{~d})\end{array}$ & $\begin{array}{l}0.118 \\
\mathrm{~L} / \mathrm{L} / \mathrm{d} \\
400 \mathrm{~mL} \\
(15 \mathrm{~d})\end{array}$ & $\mathrm{Nr}$ & $\begin{array}{l}144 \\
>100 \\
\left(\mathrm{H}_{2}+\mathrm{CH}_{4}\right)\end{array}$ & $\begin{array}{l}\text { [18] Rader } \\
\text { et al. } 2010\end{array}$ \\
\hline & \multicolumn{9}{|c|}{ MEC with selective membrane } \\
\hline Hydrogen & $\begin{array}{l}\text { Anaerobic } \\
\text { sludge }\end{array}$ & $\begin{array}{l}\text { Acetate or } \\
\text { glucose } \\
40 \mathrm{~g} / \mathrm{L}\end{array}$ & $\begin{array}{l}\text { A: Graphite felt } \\
\text { C: Carbon } \\
\text { Toray-Pd/Pt } \\
\text { Nafion } 117 \\
\text { An : } 100 \mathrm{~mL}\end{array}$ & $\begin{array}{l}0.5- \\
1.16\end{array}$ & $\begin{array}{l}0.48-0.98 \\
\mathrm{~L} / \mathrm{L}_{\mathrm{a}} / \mathrm{d}\end{array}$ & $\begin{array}{l}120-160 \\
\mathrm{~mL} / \mathrm{L}_{\mathrm{a}} / \mathrm{d}\end{array}$ & $\mathrm{Nr}$ & $\begin{array}{l}1.7-2 \\
\text { W/L H }\end{array}$ & $\begin{array}{l}{[19]} \\
\text { Tartakovsky } \\
\text { et al. } 2008\end{array}$ \\
\hline Hydrogen & $\begin{array}{l}\text { Anaerobic } \\
\text { sludge }\end{array}$ & $\begin{array}{l}\text { Acetate } \\
4 \mathrm{~g} / \mathrm{L} / \mathrm{d}\end{array}$ & $\begin{array}{l}\text { A: Graphite felt } \\
\text { C:Gas diffusion- } \\
\text { Pt Nafion } 117 \\
\text { An :50 mL }\end{array}$ & $\begin{array}{l}0.4- \\
1.15\end{array}$ & $\begin{array}{l}0.3-1.22 \\
\mathrm{~L} / \mathrm{L}_{\mathrm{a}} / \mathrm{d}\end{array}$ & $\begin{array}{l}10-20 \\
\mathrm{~mL} / \mathrm{L}_{\mathrm{a}} / \mathrm{d}\end{array}$ & $\mathrm{Nr}$ & $\begin{array}{l}3.5-5.3 \\
\mathrm{Wh} / \mathrm{L} \mathrm{H}_{2}\end{array}$ & $\begin{array}{l}{[16]} \\
\text { Tartakovsky } \\
\text { et al. } 2009\end{array}$ \\
\hline Hydrogen & $\begin{array}{l}\text { Sulfate } \\
\text { reducing } \\
\text { bacteria }\end{array}$ & $\begin{array}{l}\text { Sodium } \\
\text { sulfate 0.1-1 } \\
\mathrm{g} / \mathrm{L}\end{array}$ & $\begin{array}{l}\text { A and C: carbon } \\
\text { felt Nafion } 117 \\
\text { An: } 140 \mathrm{~mL}\end{array}$ & $\begin{array}{l}<1.48 \\
\mathrm{~V}\end{array}$ & $\begin{array}{l}1.85 \\
\mathrm{~mL} / \mathrm{mL} / \mathrm{d}\end{array}$ & $\begin{array}{l}0.008 \\
\mathrm{~mL} / \mathrm{mL} / \mathrm{d}\end{array}$ & $\mathrm{Nr}$ & $\mathrm{Nr}$ & $\begin{array}{l}\text { [20] Jafary } \\
\text { et al. } 2017\end{array}$ \\
\hline
\end{tabular}

Nr: not reported. A: anode. C: cathode. An: anolyte volume. VS: volatile solids. COD chemical oxygen demand. 


\section{Materials and methods}

\subsection{MEC design and operation}

Two-chamber MECs were constructed with glass with $135 \mathrm{~mL}$ of liquid volume and $55 \mathrm{~mL}$ of head space in each chamber. A cation exchange membrane separated the chambers $(3 \mathrm{~cm}$ diameter, CMI7000 Ultrex, U.S.A.). The anodes were constructed with carbon felt $(2 \mathrm{~cm} \times 2 \mathrm{~cm} \times 0.5 \mathrm{~cm}$, Rooe, Mexico) and the cathodes were constructed with platinum mesh (2.5 cm x $2.5 \mathrm{~cm} \mathrm{Pt:Rh} \mathrm{90:10,} \mathrm{Alfa}$ Aesar, U.S.A.). Titanium wire (1 mm diameter, Alfa Aesar, U. S. A.) was utilized for external connections. The cells were maintained at $35^{\circ} \mathrm{C}$ in a water bath [Paz-Mireles et al. 2019 21]. The anolyte consisted of an effluent from a food waste-based digester. Effluent dilutions were tested in various percentages of biomass, as shown in Table 2. A sodium phosphate buffer solution (50 mM, pH 7) containing $48 \mathrm{mM} \mathrm{KCl}$ was used as catholyte. Both chambers were flushed with nitrogen gas for $5 \mathrm{~min}$ prior operation.

The cell voltage was adjusted with a potentiostat in a two-electrode mode operation with the anode as working electrode and the cathode as reference and counter-electrode (BioLogic VSP, EC-Lab software ver. 10.12). The voltage values tested are indicated in Table 2.

The production of gaseous biofuels was monitored as explained in section 2.3.

Table 2 Codification for the MECs installed at different percentage of biomass and operated at different cell voltages.

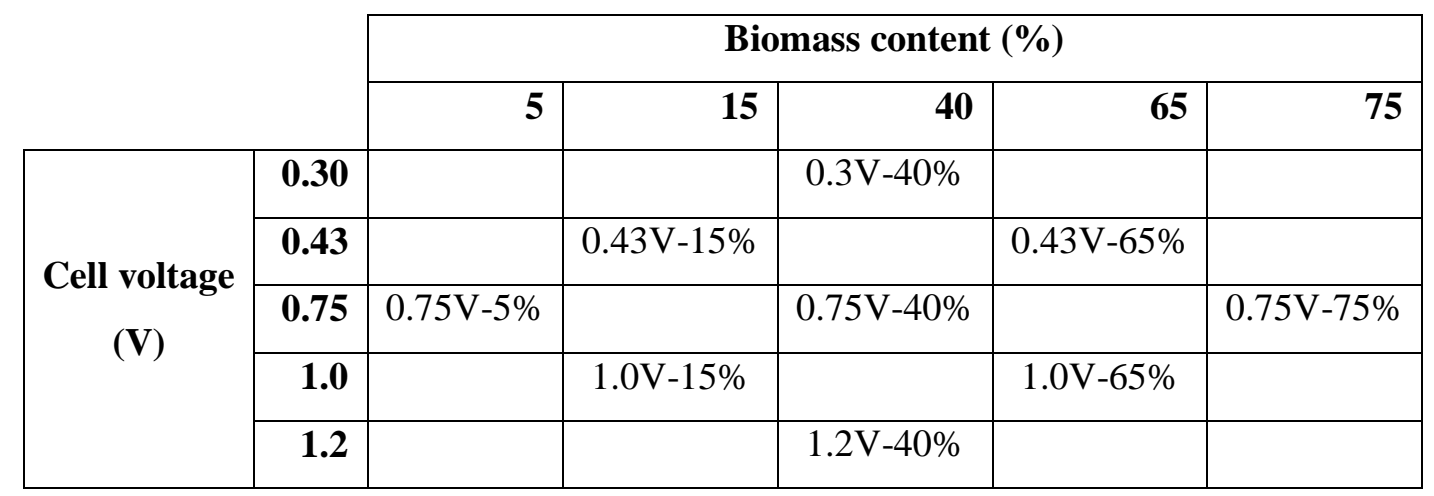

\subsection{Inoculum and substrate}


Effluents were collected from a digester inoculated with rumen, fed food wastes and operated at 35 ${ }^{\circ} \mathrm{C}$ for 129 days. Diluted effluents were used as both inoculum and substrate in the MECs. The effluents showed the following characteristics: chemical oxygen demand (COD) $30.4 \pm 6.2 \mathrm{~g} \mathrm{~L}^{-1}$, total solids $29.3 \pm 6.3 \mathrm{~g} \mathrm{~L}^{-1}$, and volatile solids (VS) $19.82 \pm 5.4 \mathrm{~g} \mathrm{~L}^{-1}$. The raw effluents were diluted with phosphate buffer solution $(50 \mathrm{mM}, \mathrm{pH} 7)$ to obtain suspensions with biomass content in the range $5-75 \%(\mathrm{v} / \mathrm{v})$ to be used as anolyte.

\subsection{Analytical techniques}

The $\mathrm{pH}$ and conductivity of the electrolytes were measured at the beginning and end of each run (Orion Star A215, U. S. A). The total COD was quantified using the reflux method for digestion of samples in a digester (Hach DRB 200, U.S.A.) and a colorimetric determination by spectrometry (Hach DR 1900, U.S.A.). Volatile solids (VS) were quantified using the APHA method [21 Rice et al. 2017]. The gas production was measured through the water displacement method, and the gas composition was analyzed in a gas chromatograph equipped with a thermal conductivity detector (SRI Instruments SRI 8610C).

Chronoamperometry was utilized as electrochemical technique to set the applied voltage between anode and cathode. The experimental charge was calculated as the area under the curve of current over time.

\subsection{Calculations}

COD and VS removal in the anodic chamber was calculated using equation (1) and (2) respectively.

CODr $\%=\frac{\operatorname{COD} f-\operatorname{COD} i}{\operatorname{COD} i} \times 100$

$V S r \%=\frac{V S f-V S i}{V S i} x 100$

where $f$ corresponds to the final values and $i$ corresponds to the initial values.

Hydrogen production was modeled with the modified Gompertz model [22 Mu et al. 2006] as shown in equation (3)

$H=H_{\max } \exp \left\{-\exp \left[\frac{H P R_{\max } \cdot e(\lambda-t)}{H_{\max }}+1\right]\right\}$ 
Where $H$ is the accumulated hydrogen volume, $H P R$ is the hydrogen production rate, the number $\mathbf{e}$ is $2.718, t$ is the elapsed experimental time, and $\lambda$ is the lag period.

Experimental charge in the MEC was measured using equation (4)

$C_{\text {exp }}=\int_{t i}^{t f} I d t$

where $I$ is the current produced in the period $\left(t_{f}-t_{i}\right)$.

Biogas yield was estimated using equation (5)

$Y_{b g / V S}=V_{b g} /(V S)_{i}$

where $V_{b g}$ is the biogas volume harvested from the anodic compartment.

Cathodic efficiency was calculated by equation (6)

$\eta_{\text {cathodic }} \%=\frac{n_{H 2, \text { exp }}}{n_{H 2, I}} \times 100$

where $n_{H 2, \exp }$ corresponds to the moles of hydrogen experimentally measured and $n_{H 2, I}$ corresponds to the moles of hydrogen calculated on basis to the produced current as indicated in equation (7)

$n_{H 2, I}=\frac{C_{e x p}}{2 F}$

where $F$ is the Faraday constant $96485 \mathrm{C} \mathrm{mol}^{-1}$.

Energy efficiency was calculated as reported by Selembo et al. (2009) [8] using equation (8)

$\eta_{\text {energy }} \%=\frac{n_{H 2, \exp } \cdot \Delta H_{H 2}}{V_{\text {app }} \cdot C_{\exp }} x 100$

where $\Delta H_{H 2}$ is the heat of combustion of $\mathrm{H}_{2}\left(-285.83 \mathrm{~kJ} \mathrm{~mol}^{-1}\right)$ and $V_{a p p}$ is the voltage applied to the MEC.

Energy consumption per produced hydrogen volume was calculated as reported by Selembo et al. (2009) [8] in equation (9)

$E_{\text {consumed } / H 2}=\frac{k W h}{V_{H 2}}$

Where $\mathrm{V}_{\mathrm{H} 2}$ is the accumulated hydrogen volume and $k W h$ is the hourly power calculated by the equation (10)

$\mathrm{kWh}=\mathrm{V}_{\mathrm{app}} \cdot \mathrm{I}_{\mathrm{avg}} \cdot\left(\mathrm{t}_{\mathrm{f}}-\mathrm{t}_{\mathrm{i}}\right)$ 
where $\mathrm{I}_{\text {avg }}$ is the averaged electrical current produced by the MECs.

\section{Results and discussion}

\subsection{Organic matter removal}

Removal of COD and VS in the anolyte was measured as a function of the $\mathrm{V}_{\text {app }}$ and the $\% \mathrm{BM}$. The COD removal increased with $\mathrm{V}_{\text {app }}$ for the MECs with $15 \%$ and $65 \%$ biomass and a maximum value of $62 \%$ was reached for the MEC $0.75 \mathrm{~V}-75 \%$ (Fig. 1A).
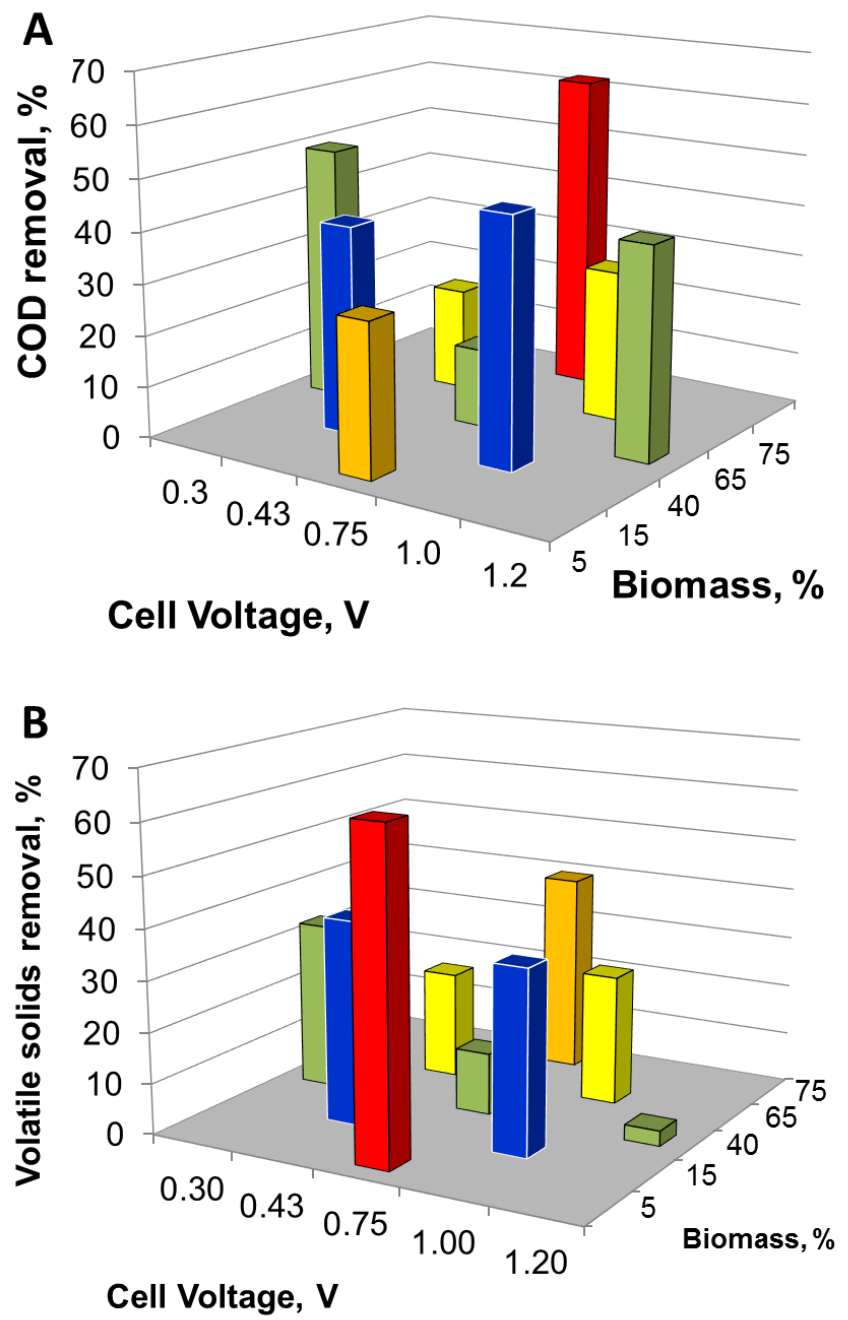
Fig. 1 Organics removal in the anodic chamber of MECs as function of applied voltage and percentage of biomass. A) Chemical oxygen demand (COD) removal, B) Volatile solids removal.

The effect of the $\mathrm{V}_{\text {app }}$ on COD removal can be direct or indirect. The direct effect is caused by the electro-oxidation of organic matter, while the indirect effect is provoked by the electrostimulation of microbial activity (i.e. oxidative metabolism).

The electro-oxidation process has been performed using carbon-based electrodes, the electrical current passing through the electrochemical cell is in the order of 1- $4 \mathrm{~A} \mathrm{~m}^{-2}$ [23 Guitaya et al. 2015] which is much higher than the current produced in MECs (Section 3.2 below).

On the other hand, the electrical field generated by the voltage between the anode and cathode has been demonstrated to modify the metabolism of microbiomes [24 Dennis et al. 2016].

Therefore, the increase in COD removal with the increase of $\mathrm{V}_{\text {app }}$ was attributed to the electrostimulation of microbial metabolism instead of electrooxidation.

Accordingly, COD removal could be enhanced by increasing the $\mathrm{V}_{\text {app }}$, and the same effect was also caused by decreasing the biomass content.

Another important parameter, the VS removal, showed a maximum of $64 \%$ for the MEC $0.75 \mathrm{~V}-5 \%$ (Fig. 1B). VS removal was higher at low $\mathrm{V}_{\text {app }}(0.3 \mathrm{~V}, 0.43 \mathrm{~V})$ in comparison with the result at high $\mathrm{V}_{\text {app }}(1.0 \mathrm{~V}, 1.2 \mathrm{~V})$ for the MECs with $15 \%$ and $40 \%$ biomass. The VS removal also was higher for low percentages of biomass $(5 \%, 15 \%)$ than for high percentages $(40 \%, 65 \%)$.

VS removal is the result of an anaerobic digestion process, i.e. microbial self-consumption; stimulus of the microbial activity by the $\mathrm{V}_{\text {app }}$ was mentioned above, however extremely high $\mathrm{V}_{\text {app }}$ diminished VS removal $(1.2 \mathrm{~V}-40 \%)$. These results suggested that the cell membranes were damaged at high $\mathrm{V}_{\mathrm{app}}$ in the whole microbiome [24 Dennis et al. 2016] which was observed as a diminution in the VS removal.

The combined effect of $\mathrm{V}_{\text {app }}$ and \% $\mathrm{BM}$ on organics removal was contradictory for the COD and VS removal. The trend for COD removal suggested operation at high $\mathrm{V}_{\text {app }}$, whereas the VS removal pointed towards an operation at low $\mathrm{V}_{\text {app }}$. Since the maximum values for both COD and VS removal were obtained with $0.75 \mathrm{~V}$, this value could be proposed in the first instance for enhancement of organics removal.

\subsection{Current density production}


Current density production from the electroactive biofilm formed from digester effluents was monitored by chronoamperometry. Representative chronoamperograms of MECs under combinations of $\mathrm{V}_{\text {app }}-\% \mathrm{BM}$ are shown in Fig. 2.
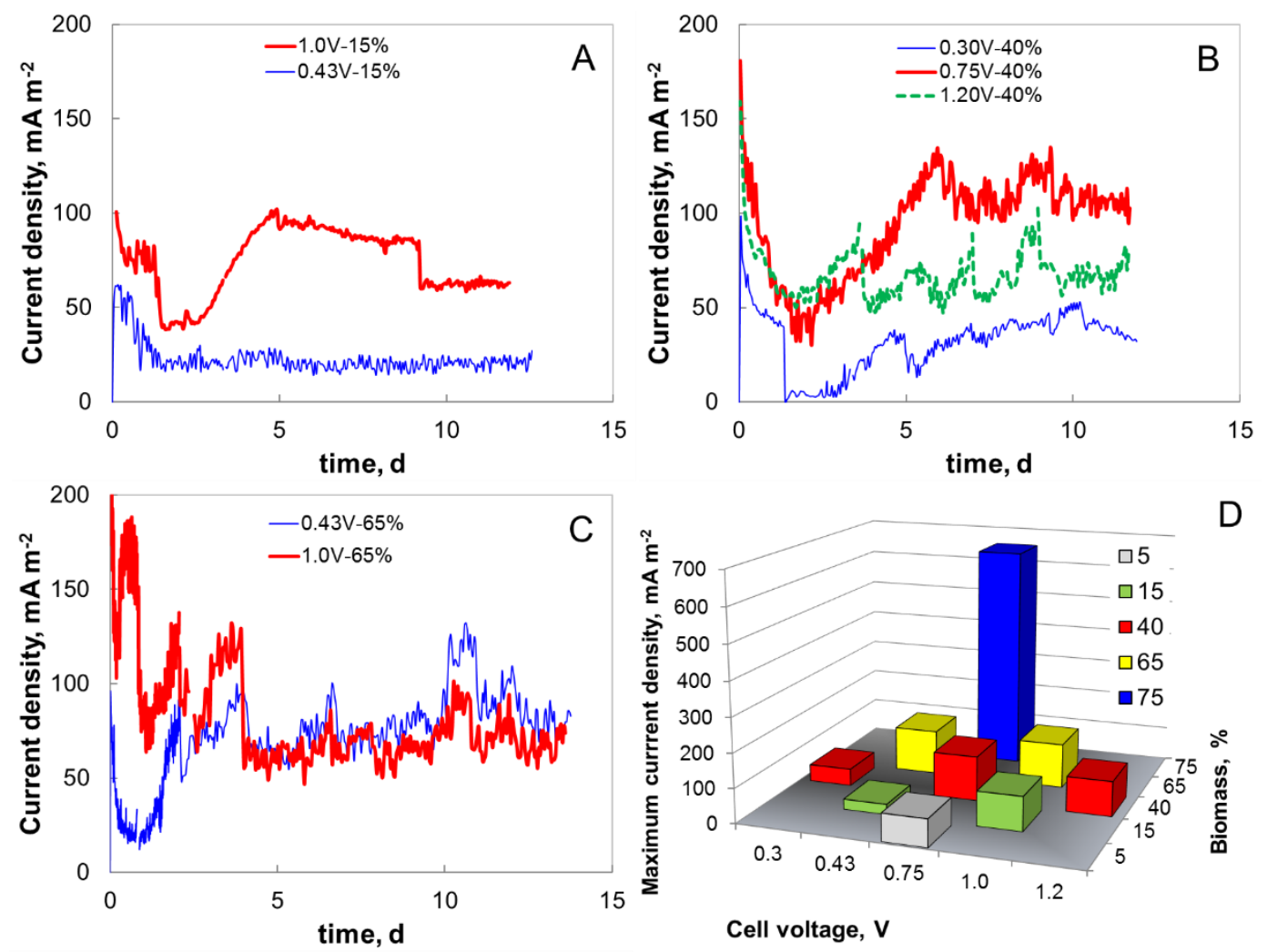

Fig. 2 Current density from bioanodes formed on carbon felt in digester effluents. Effect of applied voltage for different values (percentage) of biomass content: A) Low, 15\%, B) Medium, 40\%, C) High, $65 \%$, D) Current density maximum values as function of $\mathrm{V}_{\text {app }} \% \mathrm{BM}$.

Current density decreased within the first day most likely due to an early abiotic process. This current could be caused by the oxidation of compounds on the naked carbon felt. Transient currents are also caused by the initial charging process at the beginning of the polarization of the electrode. After the initial current declined, a fast increase was observed in most of the MECs that can be related to the development of the electroactive biofilm. The current density reached a stable phase in a period ranging 4 - 6 days. After that, the expected decline in current was not observed within the test period. This behavior suggests that MECs fed digester effluents could operate for longer periods with the advantage of no refilling the anodic compartment while keeping energy production. 
The slope of the current in the period of rapid increase seemed to be related to the percentage of biomass since slopes followed the order $15 \%<40 \%<65 \%$ irrespectively of the $\mathrm{V}_{\text {app }}$ (Fig. 2A, B, C). This observation was verified in the MECs operating at the same voltage $(0.75 \mathrm{~V})$ with increasing biomass content from $5 \%$ to $40 \%$ to $75 \%$, which presented maximum currents of 80 $\mathrm{mA} \mathrm{m}{ }^{-2}, 130 \mathrm{~mA} \mathrm{~m}^{-2}$ and $650 \mathrm{~mA} \mathrm{~m}^{-2}$ respectively. From a practical point of view, this observation might be applied to obtain a fast startup of MECs.

All the MECs produced an increase in current density except the MEC $0.43 \mathrm{~V}-15 \%$. This result is most likely caused by the combination of low values of both $\mathrm{V}_{\text {app }}$ and \%BM.

If the MECs are fed with low biomass content, a high cell voltage might be required, although an optimum value must be selected to avoid cell damage [27 Ying et al. 2017]. In that sense, an optimum $\mathrm{V}_{\text {app }}$ was observed in the MECs operated at $40 \%$ biomass; current density increased when the $\mathrm{V}_{\text {app }}$ increased from $0.3 \mathrm{~V}$ to $0.75 \mathrm{~V}$, but thereafter the current decreased at $\mathrm{V}_{\text {app }}$ of $1.2 \mathrm{~V}$ (Fig. 2B).

The combination of both high \% BM $(65 \%)$ and high $\mathrm{V}_{\text {app }}(1.0 \mathrm{~V})$ was expected to enhance the maximum current density, but although a high current was observed initially, it decreased rapidly within the first day to be later stabilized, reaching a current density similar to that observed at 0.43 V (Fig. 2 C). This behavior could be due to a fast consumption of easily degradable substrate such as it was modeled by Alavijeh et al. [2015 28] and the results presented here suggests that the applied voltage might have no effect on the stationary current density for MEC installed with high biomass content.

The combination $0.75 \mathrm{~V}-75 \%$ seemed to be the most adequate to enhance current production (Fig. 2D). in concordance with maximum COD removal (Fig 1A).

Overall, if digester effluents are fed to MECs, the electrical current could be produced for extended periods due to sustained supply of simple molecules from complex substrates; high biomass content enables higher current density that can be reached in a shorter time, which is useful at the start up stage. However, the current density seemed to be independent of applied voltage when extremely high biomass content is used. In regard to the organics removal and electrical current production, the combination $0.75 \mathrm{~V}-75 \%$ seems to be adequate to install and operate MECs.

\subsection{Cathodic hydrogen gas production}


Hydrogen production was observed only in 5 of the 9 combinations $\mathrm{V}_{\text {app }}-\mathrm{BM} \%$ which are shown in Fig. 3. The lag period was 2-7 days, the shortest lag period was obtained with $0.43 \mathrm{~V}-65 \%$, the longest with $1.0 \mathrm{~V}-65 \%$, and no hydrogen was produced at $1.2 \mathrm{~V}$.

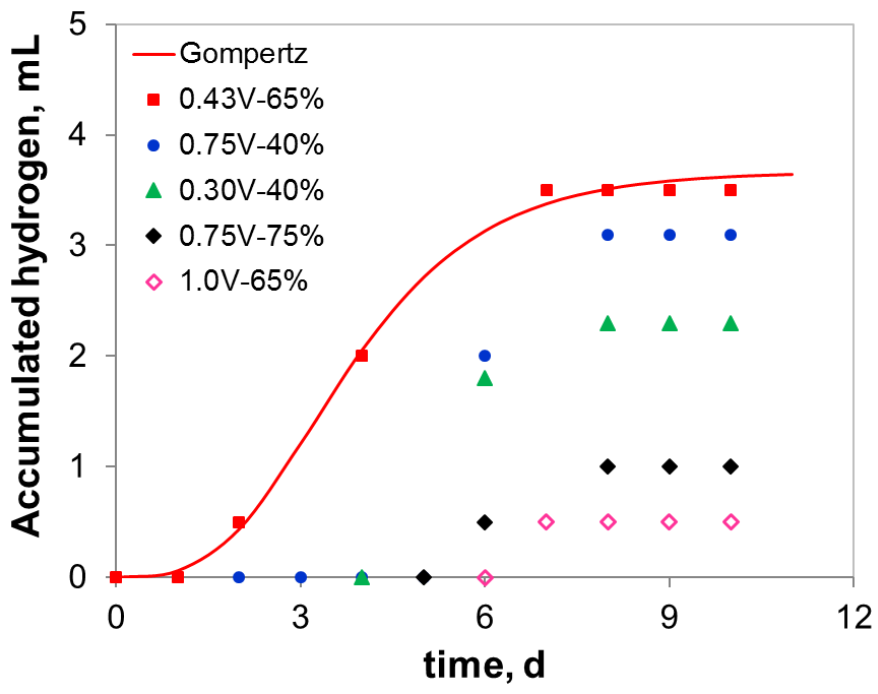

Fig. 3 Evolution of cathodic hydrogen at different applied voltages and percentages of biomass. Markers indicate experimental data and continuous line is an example of fitting to the modified Gompertz model.

The maximum hydrogen production rate from the modified Gompertz model ranged $1.0 \mathrm{~mL} \mathrm{~h}^{-1}$ to 4.1 $\mathrm{mL} \mathrm{h}^{-1}$ (Table 3).

Table 3 Experimental and modeled data for hydrogen production in MECs as function of applied voltage and percentage of biomass.

\begin{tabular}{|c|c|c|c|c|c|}
\hline \multirow[t]{2}{*}{ MEC } & \multicolumn{2}{|c|}{$\begin{array}{l}\text { Lag period } \\
\text { (d) }\end{array}$} & \multicolumn{2}{|c|}{$\begin{array}{l}\text { Maximum volume } \\
\qquad(\mathrm{mL})\end{array}$} & \multirow{2}{*}{$\begin{array}{l}\text { Maximum production rate } \\
\qquad\left(\mathbf{m L ~ d}^{-1}\right) \\
\text { Model }\end{array}$} \\
\hline & Experimental & Model & Experimental & Model & \\
\hline $0.43 \mathrm{~V}-65 \%$ & 1 & 1.5 & 3.5 & 3.6 & 1.0 \\
\hline $0.75 \mathrm{~V}-40 \%$ & 4 & 5.2 & 3 & 3.1 & 3.4 \\
\hline $0.30 \mathrm{~V}-40 \%$ & 4 & 5.0 & 2.3 & 2.3 & 3.2 \\
\hline $0.75 \mathrm{~V}-75 \%$ & 5 & 5.8 & 1 & 1.0 & 4.1 \\
\hline $1.0 \mathrm{~V}-65 \%$ & 6 & 6.2 & 0.5 & 0.5 & 3.0 \\
\hline
\end{tabular}


Modeled parameters fitted well with the experimental values. Lag periods can be expected from 1.5 to 6.2 days in the experimental set up utilized. Interestingly, the accumulated hydrogen volume seemed to be inversely proportional to the production rate, and the maximum production rate was verified for $0.75 \mathrm{~V}-75 \%$ in correspondence to COD removal and current density results.

No correspondence between hydrogen volume and organics removal (COD and VS) was found due to the low anode to anolyte ratio (2:135). The formation of hydrogen gas at the cathode is a result of the electrical charge generated from the biofilm on the small anode, while the organics removal is mostly due to the activity of planktonic microorganisms in the anolyte; thus, only for packed reactors the yield $\mathrm{H}_{2}$ volume/COD removal is a reliable information.

Hydrogen production correlated with the maximum current density values since experimental electrical charge is a supply for the formation of hydrogen gas on the cathode. However, that correlation was not entirely direct, for instance the maximum current density was obtained for MEC $0.75 \mathrm{~V}-75 \%$ but the maximum hydrogen volume did not correspond to that cell. Parasitic reactions likely occurred on the cathode which hindered a higher hydrogen productivity.

Overall, hydrogen production seemed to be inhibited by high cell voltages, an interesting inverse relation between production rate and accumulated hydrogen volume was found. This point requires additional investigation, and may be related to possible parasitic reactions on the cathode. In regard to hydrogen production, the $0.43 \mathrm{~V}-65 \%$ MEC seems to be the best combination because of its shortest lag period and highest accumulated volume, but the $0.75 \mathrm{~V}-75 \% \mathrm{MEC}$ is better in terms of the hydrogen production rate.

\subsection{Anodic biogas production}

Biogas production was obtained in 5 of the 9 combinations of $\mathrm{V}_{\text {app }}-\% \mathrm{BM}$ as shown in Fig. 4. No biogas was produced with low biomass content (5\% and $15 \%$ ). The lag period was 1-6 days and it was shorter for the MECs with high biomass content (65\% and $75 \%)$. 


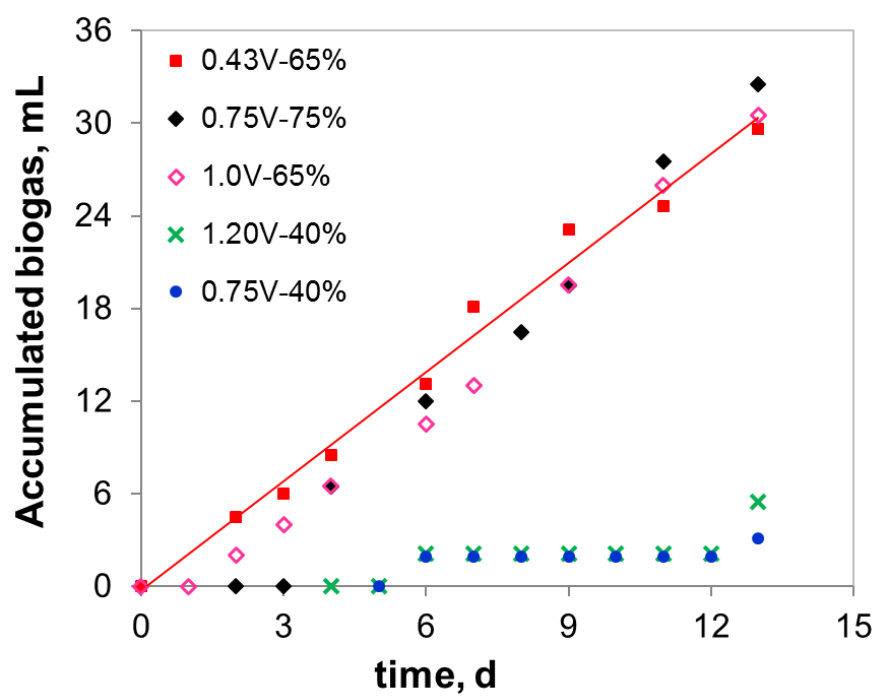

Fig. 4 Evolution of anodic biogas. Markers signal experimental data and continuous line is an example of linear fit of data.

Biogas production rate was almost linear for the MECs with $65 \%$ and $75 \%$ of biomass. A model of linear regression was applied to the data showing fit of $\mathrm{R}^{2}=0.98-0.99$. The equation for biogas production was established as $m L_{\text {biogas }}=(2.65 \pm 0.29)$ day $-(3.5 \pm 2.9)$ with a coefficient of variation of $11 \%$ for the gradient. The regression equation is a first approach for biogas production in the specific experimental setup utilized.

The accumulated biogas volume ranged from $31 \mathrm{~mL}$ to $33 \mathrm{~mL}$ in 13 days and no decline in production was observed so the process possibly could be continued. The maximum biogas volume corresponded to the MEC $0.75 \mathrm{~V}-75 \%$, which also presented the highest hydrogen production rate, current density and COD removal.

Interestingly biogas production rate and methane content showed an inverse behavior (Fig. 5). The percentage of methane in biogas followed the order $69 \%<75 \%<87 \%$ for the MECs with production rate of $21.8>19.7>17.5 \mathrm{~mL} \mathrm{~L}^{-1} \mathrm{~d}^{-1}$ respectively. A similar behavior was also described by Tartakovsky et al. [2008 19]. Given the positive impact of this observation, it is intended to investigate this phenomenon in depth. 


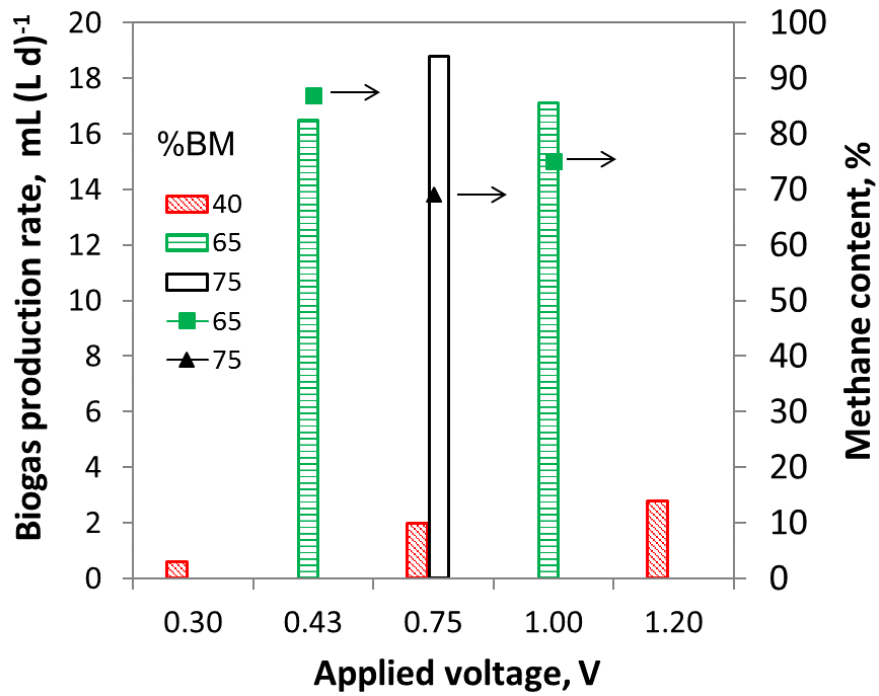

Fig. 5 Effect of applied voltage on biogas production rate and methane content in MECs operated at different applied voltage and biomass content (\%BM).

The accumulated volume of biogas was not affected by $\mathrm{V}_{\text {app. }}$, while biogas production rate increased with the applied voltage. Nevertheless, that trend seemed to be a function of the biomass content because the improvement was less important with $65 \%$ biomass than with $40 \%$ biomass. The methane content tended to decrease with the increase of applied voltage, in agreement with previous reports [Call and Logan, 2008 10, Escapa et al. 2013 17, Wang et al. 2009 15, Feng et al $201511]$.

In summary, biogas was produced only with high biomass content and its production was uninterrupted which can provide a longer operation process; the effect of $\mathrm{V}_{\text {app }}$ on biogas productivity was divergent: accumulated volume showed not to be affected, production rate increased with the voltage whilst methane content decreased.

\subsection{Dual production of gaseous biofuels}

Hydrogen and biogas were produced in volumes of $3.5 \mathrm{~mL}$ in 8 days and $33 \mathrm{~mL}$ in 13 days. The results were similar to those reported by Feng et al. [2015 11] using sludge as inoculum and substrate; the authors reported a production of 3.5-7.5 mL hydrogen in 5 days and 10-170 $\mathrm{mL}$ of methane in 20 days (Table 1).

The maximum hydrogen volume was reached in a shorter time than biogas; therefore, for a simultaneous dual production, the assessment of an optimal operation time is necessary. Another influencing factor is the installation of a selective membrane. The membrane enables separation of 
gaseous currents and facilitates the subsequent gas cleaning procedures, enables the cathode integrity for long-time operation but also increases the installation cost. On the other hand, membrane-less reactors hampers dual production because the reactants consumption via hydrogenotrophic and acetoclastic methanogens [Ruiz et al. 2013 13].

The main challenge in regard of dual production is to define the criteria under which installation and operation selections will be made. Performance in terms of organics removal, gas volume, production rate, methane content, as well as installation considering biomass content or applied voltage are in all the most critical parameters. Decisions should be taken not only on the basis of gases productivity but also considering an efficiency and economic analysis.

In the previous sections, the combination $0.75 \mathrm{~V}-75 \%$ and $0.43 \mathrm{~V}-65 \%$ seemed to be the more adequate to accomplish the main performance criteria, this was contrasted with an analysis of efficiencies of the process.

\subsection{MEC efficiencies}

Table 4 Performance of MECs inoculated and fed with effluents from a food waste digester and operated at various combinations of voltage and biomass content.

\begin{tabular}{|c|c|c|c|c|c|}
\hline $\begin{array}{c}\text { MEC } \\
\text { operation } \\
\text { condition }\end{array}$ & $\begin{array}{c}\text { Normalized } \\
\qquad \mathbf{H}_{2} \\
\text { production } \\
\text { (mmol m² } \\
\text { cathode) }\end{array}$ & $\begin{array}{c}\text { Energy } \\
\text { consumption } \\
\text { for } \mathbf{H}_{2} \\
\text { production } \\
\left(\mathbf{k W h ~ m}^{-3}\right)\end{array}$ & $\begin{array}{c}\begin{array}{c}\text { Energy } \\
\text { efficiency }\end{array} \\
\text { for } \mathrm{H}_{2} \\
\text { production } \\
(\%)\end{array}$ & $\begin{array}{l}\text { Biogas yield } \\
\left(\mathrm{mL} \mathrm{\textrm {g } ^ { - 1 }} \mathrm{VS}\right)\end{array}$ & $\begin{array}{c}\text { Methane } \\
\text { production } \\
\text { rate } \\
\left(\mathrm{mL} \mathrm{L}^{-1} \mathbf{d}^{-1}\right)\end{array}$ \\
\hline $0.75 \mathrm{~V}-5 \%$ & 0 & 0 & 0 & 0 & 0 \\
\hline $0.43 \mathrm{~V}-15 \%$ & 0 & 0 & 0 & 0 & 0 \\
\hline $1.06 \mathrm{~V}-15 \%$ & 0 & 0 & 0 & 0 & 0 \\
\hline $0.30 \mathrm{~V}-40 \%$ & 268 & 0.38 & 854 & 3.3 & $\mathrm{Nr}$ \\
\hline $0.75 \mathrm{~V}-40 \%$ & 346 & 2.0 & 178 & 31.3 & $\mathrm{Nr}$ \\
\hline $1.20 \mathrm{~V}-40 \%$ & 11 & 64.5 & 5 & 165.0 & $\mathrm{Nr}$ \\
\hline $0.43 \mathrm{~V}-65 \%$ & 391 & 0.71 & 336 & 92.1 & 14.4 \\
\hline $1.06 \mathrm{~V}-65 \%$ & 55 & 12.2 & 20 & 78.9 & 12.8 \\
\hline $0.75 \mathrm{~V}-75 \%$ & 112 & 36.0 & 13 & 48.8 & 13.0 \\
\hline
\end{tabular}

Nr: Not reported 
Normalized hydrogen production ( $\mathrm{mmol} \mathrm{H}_{2} \mathrm{~m}^{-2}$ cathode) is proposed as a parameter to group pressure, temperature and the cathode area, which are commonly reported for abiotic electrolyzers [Wendt H. 1990 34]. The normalized hydrogen molar production ranged 11-391 mmol m${ }^{-2}$ cathode and the highest value was obtained for the combination $0.43 \mathrm{~V}-65 \%$.

Energy consumption is proportional to $\mathrm{V}_{\text {app }}$ for any type of electrolyzer. This parameter ranged 0.38-64.5 $\mathrm{Wh} \mathrm{m}^{-3}$. The lowest energy consumption was obtained for $0.3 \mathrm{~V}-40 \%$.

The use of electroactive microorganisms as biocatalyst instead of precious metals has been claimed as the main advantage of MECs. Bioanodes reduce the overpotential of the electrochemical cell, so they are expected to reduce the energy consumption. In addition, the energy demand for hydrogen volume from water electrolysis is reported as $0.6-0.9 \mathrm{kWh} \mathrm{m}^{-3}$, but for alkaline electrolysis that demand increases to 3-5 $\mathrm{kWh} \mathrm{m}^{-3}$ [Pletcher and Walsh 1990 38]. Therefore, the systematic calculation on energy consumption for MECs enables to verify the MEC advantages over abiotic electrolyzers. Tartakovsky et al. [2008 19] estimated 1.7-2 $\mathrm{W} \mathrm{L}^{-1}\left(1.7-2 \mathrm{~kW} \mathrm{~m}^{-3}\right)$ operated in the range $0.5-1.16 \mathrm{~V}$ which also verified an advantage over abiotic electrochemical systems for hydrogen production.

Energy efficiency is the ratio of the energy from the accumulated hydrogen volume to the energy supplied to the MEC as voltage over the operation time. This efficiency must be superior to $100 \%$ to attain a net energy gain. The energy efficiency ranged 5-805\% and the maximum value was obtained also for $0.3 \mathrm{~V}-40 \%$.

The highest energy efficiency reported for dual gas production is as high as $406 \%$ obtained in a 28 $\mathrm{mL}$ MEC by Call and Logan [2008 10]. The foreseeable challenge for these promising results is scaling MECs while maintaining the energy efficiency.

Biogas yielded 3.3-165 $\mathrm{mL} \mathrm{g}^{-1} \mathrm{VS}$. The highest value was due to negligible VS removal at $1.2 \mathrm{~V}$ MEC operation (Fig. 1B), therefore this data was discarded and $0.43 \mathrm{~V}-65 \%$ was selected as the best combination to enhance biogas yield. Methane production rate varies widely in literature (Table 1), the results obtained in the present work were similar to those reported by Tartakovsky et al. (2009 16).

Methane content followed the same behavior as biogas yield. Wang et al. [2009 15] reported $50 \%$ methane in biogas in $3 \mathrm{~d}$ of MEC operation, but Hou et al. [2015 37] reached $95 \%$ over $74 \mathrm{~d}$; in the present work, a maximum of $87 \%$ methane was reached in $13 \mathrm{~d}$. Comparison of methane content and operation length highlight that the challenge for biogas production in MECs is to increase methane content at lower operation time. 
Functions of MECs include wastewater treatment, energy production, and bioelectrochemical synthesis; at last one of them determines the installation and operation conditions. Based on the gaseous biofuels production, the $0.75 \mathrm{~V}-75 \%$ was the best combination as described in Sections 3.1, 3.2, and 3.4; nevertheless, efficiency estimations highlighted $0.30 \mathrm{~V}-40 \%$ and $0.43 \mathrm{~V}-65 \%$ as the best operation mode.

These findings are of great importance because they show that it is necessary to systematically extend the analysis of gas productivity to energy efficiencies, especially when two products or more are harvested.

Since the market value for hydrogen differs from that for biogas, the final selection needs to be made on the basis of an economic analysis.

\subsection{Economic benefit of dual production of gaseous biofuels}

Once determined the combination $\mathrm{V}_{\mathrm{app}}-\% \mathrm{BM}$ to enhance the energy efficiency, both hydrogen and biogas productivities were taken as basis to estimate the US dollars gain per kilogram of removed COD. In this way, the three functions of MECs were integrated.

Information on sale prices for gaseous biofuels, and electricity cost was obtained from U.S.A. government reports [Peterson and Zelenay, 2014 39, Beddoes et al. 2007 40, Genovese et al. 2009 41].

A balance between the product value and the operation cost (electricity cost) was performed. The balance showed that the economic benefit for the MEC $0.3 \mathrm{~V}-40 \%$ and the MEC $0.43 \mathrm{~V}-65 \%$ was 0.001 and $0.01 \mathrm{USD} \mathrm{kg}^{-1} \mathrm{COD}$ removed respectively for an operation period of 13 days.

Comparison of economic gain highlighted that it is preferable to aim high biogas productivity than high hydrogen productivity. The economic gain from biogas was ten-fold higher in MEC 0.43V$65 \%$ than for hydrogen productivity in MEC $0.3 \mathrm{~V}-40 \%$ due to the biogas produced in comparison with hydrogen gas produced. Moreover, the surplus of hydrogen increased the USD gain/COD removed in $20 \%$ for MEC $0.43 \mathrm{~V}-65 \%$ (Table 5).

Table 5 Comparison of economic benefits obtained from the MECs with the maximum energy efficiencies. Price of fuels 5.1 USD/ $\mathrm{kg} \mathrm{H}_{2}$ and $0.193 \mathrm{USD} / \mathrm{m}^{3}$ biogas [Peterson \& Zelenay 2014 39, Beddoes et al. 2007 40].

\begin{tabular}{llllll}
\hline Maximum & MEC & Hydrogen & Biogas & USD gain & USD/COD \\
\hline
\end{tabular}




\begin{tabular}{llllll}
\hline $\begin{array}{l}\text { energy } \\
\text { obtained from }\end{array}$ & $\begin{array}{l}\text { operation } \\
\text { conditions }\end{array}$ & $\begin{array}{l}\text { production } \\
\mathbf{( k g})\end{array}$ & $\begin{array}{l}\text { production } \\
\left(\mathbf{m}^{\mathbf{3}}\right)\end{array}$ & $\begin{array}{l}\left(\mathbf{H}_{2}+\text { biogas }\right) \\
\text { removed }\end{array}$ & \\
\hline Hydrogen & $0.3 \mathrm{~V}-40 \%$ & $2.14 \times 10^{-7}$ & $1.0 \times 10^{-6}$ & $1.29 \times 10^{-6}$ & 0.001 \\
Biogas & $0.43 \mathrm{~V}-65 \%$ & $3.12 \times 10^{-7}$ & $29.0 \times 10^{-6}$ & $7.19 \times 10^{-6}$ & 0.010 \\
\hline
\end{tabular}

The double productivity of gaseous fuels must be tested for other MEC systems. A $20 \%$ gain could be different with other substrates, inoculum, electrode material and cell design, the difference may change decision making. Here we present a methodology and several challenges to move towards the integration of MECs with other bioprocesses.

\section{Outlook and challenges}

MEC technology is still in an early stage of development, but shows a great promise as multiple products are obtained from them. Initial research in MECs focused on hydrogen gas, followed by methane production, nevertheless dual gaseous biofuels production may enhance the already stablished benefits.

Investigation at laboratory and pilot scale is growing very rapidly, but rarely both types of studies are performed by the same research group. Therefore, uncertainty is dragged when laboratory scale data are extrapolated for either pilot scale studies or technical-economic analyses. For that reason, we proposed a methodological strategy to be extended to other MEC systems at laboratory scale to supply technical data.

Interesting questions to investigate in depth were found along the present research and are listed below as a guide for further works.

i) Microorganisms. The effect of applied voltage on the microbial metabolism might differ at low or high $\mathrm{BM} \%$ for the same mixed bacterial consortium. Pure cultures isolated from the consortium in both planktonic and sessile growth could be evaluated at different applied voltages and different microbial biomass content.

ii) Metabolic pathways and electrode reactions. Flux of hydrogen ions splits toward methane formation in the anodic chamber and toward hydrogen gas formation in the cathodic chamber. Knowledge on the fluxes ratio might help to control the process. 
iii) Electrode side-reactions at the cathode resulting in energy efficiency higher than $100 \%$, as well as the specific compounds that originate the electrical charge for hydrogen formation need more investigation.

iv) The inverse relation between biogas production rate and methane content in biogas need to be explored since this observation has also been reported before but remains unexplained and could be of great economic interest.

v) Installation and large scale application. The integration of MECs with waste-to-energy technologies could be more realistic as MECs are scaled. Bioanode size must provide enough charge for the hydrogen evolution reaction, but if this reaction is the limiting step, bioanode could be improved with modified materials.

vi) Membrane installation. Since the experimental set up used did not provide the greater benefit via hydrogen production, the use of alternative materials for the electrode separation is suggested. MECs are seen as a sequential second process for anaerobic digestion or for hydrogen fermentation, however scarce attention has been put on discharges from MECs, this topic should be also considered in a global integration of MEC to other processes.

vii) Integration of technologies. New technologies to full-scale processes could start via complementary low-cost installation. Hydrogen and biogas production are complementary products in various schemes: Upgrading biogas with methane, syngas production from waste gases and hydrogen is also possible.

A systematic progression for scaling MECs is needed, calculations of energy efficiency and economic benefits must be included at each scaling step since the cost and value of electricity would vary from a country and location to another. Operating conditions that maximize the benefits of MECs must be strategically selected, especially when only one from depollution, energy production, and economic benefit is priority.

\section{Acknowledgments}

This study was financially supported by the CONACYT-SENER-FSE (Project 247006) and SEPCONACYT (project 177441). The authors acknowledge the use of potentiostat/galvanostat BioLogic VSP (series 1194) from IPICYT.

\section{References}




\section{Glossary}

$\% \mathrm{BM}$ Percentage of biomass

COD Chemical oxygen demand

MEC Microbial electrolysis cell

$\mathrm{V}_{\text {app }}$ Applied voltage

VS Volatile solids 